\title{
炭素鋼の高温叔よ゙室温における疲学強度に 及济す表面あらさの影響*
}

\section{安藤善司 ${ }^{* *}$ 土田幸滋***中野，典 楌**}

\section{The Influence of Surface Roughness on the Fatigue Strength of Carbon Steel at Elevated and Room Temperatures}

by

\author{
Zenji ANDō \\ (Faculty of Engineering, Gifu University, Kagamigahara) \\ Kōji Tsuchida \\ (Faculty of Technology, Tokyo Metroporitan University, Tokyo) \\ and Norihiko NAKANO \\ (Faculty of Engineering, Gifu University, Kagamigahara)
}

The rotating bending and push-pull fatigue tests were carried out on $0.29 \%$ carbon steel specimens with four kinds of surface roughness at room temperature, $250^{\circ} \mathrm{C}$ and $350^{\circ} \mathrm{C}$, where the strain aging is most remarkable.

The results obtained are as follows :

(1) At room temperature, the fatigue strength decreases as the degree of the surface roughness increases.

(2) At $250^{\circ} \mathrm{C}$ and $350^{\circ} \mathrm{C}$, it is not possible to find any general tendency for the relation between the surface roughness and the fatigue strength, because of the scatter of fatigue strength data, the difference in stress level between the rotating bending and push-pull, the change in surface roughness caused by the formation of oxide scale, the change of hardness by repeated stress and so on.

(3) At $250^{\circ} \mathrm{C}$ and $350^{\circ} \mathrm{C}$, in spite of the difference in surface roughness, the $S-N$ curves can be divided remarkably into two groups, one for the mechanically finished specimens and the other for the specimens annealed in vacuum after mechanical finishing.

(Received Mar. 30, 1974)

\section{1 緒言}

機械部品の表面仕上は, 一般に, 切削, 研削あるい はたく摩などの機械的な方法で行なわれる。このよう な仕上げ加工は表面あらさをはじめとして, 加工硬化 あるいは残留応力などにより, 疲労強度に影響を及ぼ すことが広く知られている。筆者らの一人は先に, $0.09 \% \mathrm{C} ， 0.29 \% \mathrm{C}$ 打よび $0.51 \% \mathrm{C}$ 炭素鋼について, それぞれ 4 種類のあらさに機械仕上げした試験片，お よび機械仕上げ後低温真空燒なましした試験片を用い て, 回転曲げ痩労試験を行ない, $0.29 \% \mathrm{C}$ 炭素鋼の場 合に, 疲労強度に及ぼす表面あらさの影響が最も大き

* 原稿受理 昭和49年 3 月30日

** 正会員 岐皁大学工学部 各務原市那加門前町

*** 学生会員 東京都立大学大学院 東京都世田谷区深次
いといら結果を得た。 な拈, 先の研究は室温で疲労試 験を行なったが, 従来のこの分野の研究も室温の場合 がほとんどである。

しかし, 高温ではひずみ時効による複雑な現象の生 じることも考えられるが，このことをも考慮した研究 は汪とんどなされていない、そこで本研究は, 高温お よび室温において, 表面あらさとそのあらさの製作に 伴ら加工変質層が疲労強度に及ぼす影響を調べるため, 次のような研究を行なった。すなわち, 室温において 表面あらさが回転曲げ疲労強度に及ぼす影響の最も大 きい $0.29 \% \mathrm{C}$ 炭素鋼を用いて, ひずみ時効の最も著し い $350^{\circ} \mathrm{C}$, および $350^{\circ} \mathrm{C}$ と室温との中間の温度として $250^{\circ} \mathrm{C}$ を選び，4 種類のあらさの試験片について回転 曲げ疲労試験を行なった。 また, 試験片表面部の加工 
硬化と残留応力, 扣よび残留応力の疲労過程に伴ら変 化を調べた。 これと同様な実験を室温，250C 抢よび $350^{\circ} \mathrm{C}$ に和いて，引張圧縮についても行ない,これら の結果に室温に和ける回転曲げ疲労試験結果を加えて 比較検討した。

\section{2 試験片および実験方法}

供試材は $0.29 \% \mathrm{C}$ 炭素鋼で，その化学成分および機 械的性質を Table I に示す。素材を Table II に示 す最終加工条件により，エメリ一紙あるいはノーズ半 径 $1 \mathrm{~mm}$ の剣バイトを用い，1S，3S，7S 执よび $12 \mathrm{~S}$ の 4 種類の表面あらさで, Fig. 1 の形状寸法に仕上げ た.ここで各あらさは，それぞれ所定の範囲のあらさ を代表するものである．表面のあらさは触針式仕上面 検査器で測定し, 所定のあらさ範囲以外のものは除外 した. 試験片の約半数は加工に伴う残留応力をできる だけ除去するため， $650^{\circ} \mathrm{C} て ゙ 1$ 時間の低温真空焼なま しを行なった，以下，機械仕上のままの試験片を非焼 なまし材，機械仕上げ後低温真空焼なましした試験片 を焼なまし材と呼ぶこととする。使用した試験機は 小野式回転曲げ疲労試験機（3200 rpm）执よび 共振 型 1 ton 引張圧縮疲労試験機 (1800 rpm) である.

Table I. Chemical composition and mechanical properties of the material.

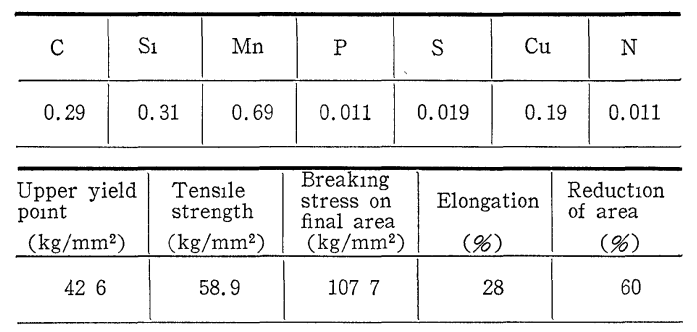

Table II. Finishıng condition.

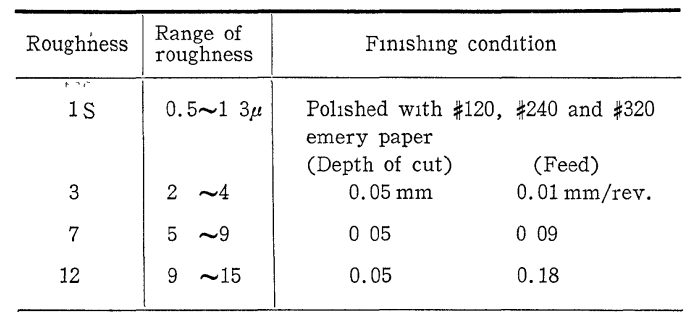

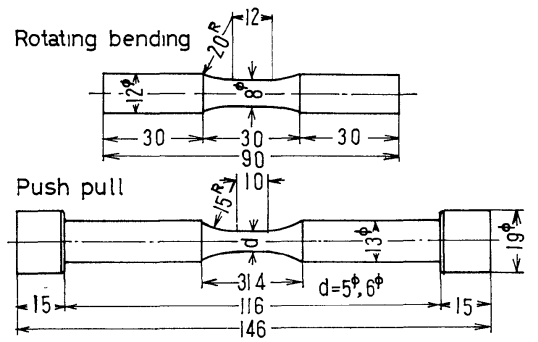

Fig. 1. Specimens for fatigue test.
試験片の表面より電解研摩で逐次薄層を除去し, 微小 かたさ計で各深さのかたさを測定した，測定荷重は表 面あらさ $12 S$ についてもかたさ測定ができるように $500 \mathrm{~g}$ とした．かたさは各深さに和いて10点の平均值 で示した．加工層の残留応力は電解研摩で逐次薄層を 除去し, 軸方向の残留応力を平行ビーム型X線回折装 置で計数管法により測定した。その測定条件は，特性 $\mathrm{X}$ 線 $\mathrm{Cr}-\mathrm{K} \alpha$ 線，管電圧 $28 \mathrm{KV}$ ，管電流 $10 \mathrm{~mA}$, 時 定数 $20 \mathrm{sec}$, , ピーク位置決定は半価幅法とし, $\sin ^{2} \psi$ 法で残留応力を求めた。

\section{3 実験結果および考察}

\section{$3 \cdot 1$ 回転曲げ疲労試験}

$3 \cdot 1 \cdot 1$ かたさ分布 非焼なまし材および焼なま し材の表面付近のかたさの測定結果をFig. 2 に示す. 加工硬化層は表面あらさの゙大きいるの注ど増大する。 また，焼なましにより表面の加工硬化は泳ぼ半減する が，加工硬化層の深さはあまり変わらず，約 $10 \sim 50 \mu$ である。

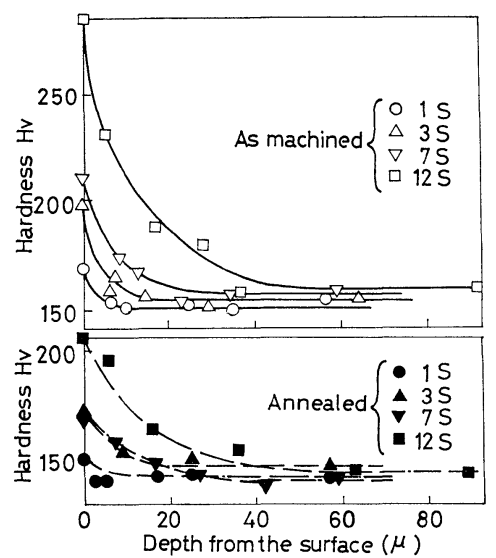

F1g. 2. Hardness distributions of specimens (rotating bending).

$3 \cdot 1 \cdot 2$ 残留応力の分布 残留応力の測定結果を Fig. 3 に示す. 非焼なまし材の場合，エメリ一紙仕上 ゲした 1S は，旋削仕上げした 3S，7S 括よび $12 S$ よ り大さな圧縮残留応力を生じている。これらの残留応 力は焼なましによりほぼ消隇する。

$3 \cdot 1 \cdot 3$ 温度と疲労強度の関係 Fig. 4 はあらさ

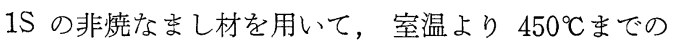
温度に怙いて回転曲げ疲労試験を行なった結果である。 後述するが, 高温の場合はかなりのばらつきを生じて いる. Fig. 4 を温度と時間強度について整理すると Fig. 5 のようになり, どの時間強度についてもよく一 致した傾向を示す。添 $350^{\circ} \mathrm{C}$ 付近で疲労強度が最大 となり，ひずみ時効は $350^{\circ} \mathrm{C} て ゙$ 最も著しく，250 Cでは それよりやや劣る. 


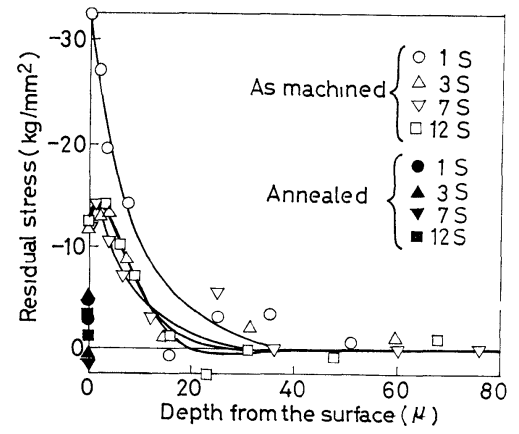

Fig. 3. Distributions of residual stress of specimens (rotating bending).

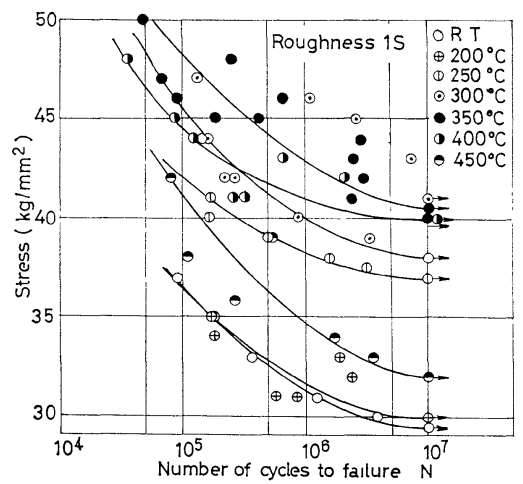

Fig. 4. $S-N$ curves at various temperatures (rotating bending).

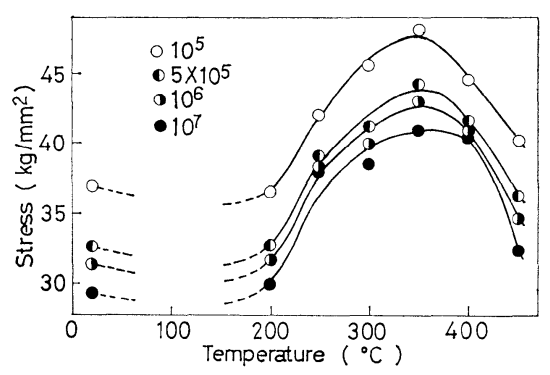

Fig. 5. Relation between fatigue strength and temperature (rotating bending).

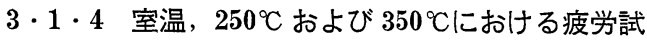

験 室温に批疲労試験結果をFig. 6 亿示す. 非焼 なまし材, 焼なむし材ともにあらいもの注ど疲労強度 が低下し，そのあらさによる疲労限度の差は非焼なま

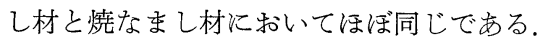

Fig. 7 (a)k 1S の試験片の室温での疲労過程に伴う 残留応力の変化を示す. $10^{3} \sim 10^{7}$ 回拈よび疲労試験前 （100回にプロットする）の残留応力は注涪直線上に のっており, 指数関数的に減少し, その減少割合は繰 返し応力が高い汪ど大きい. Fig. 7(b)は 7S の非焼な まし材の場合である。エメリー紙仕上げした $1 \mathrm{~S}$ とほ ぼ同じ傾向を示す，Fig. 7 にみられるように，非焼な

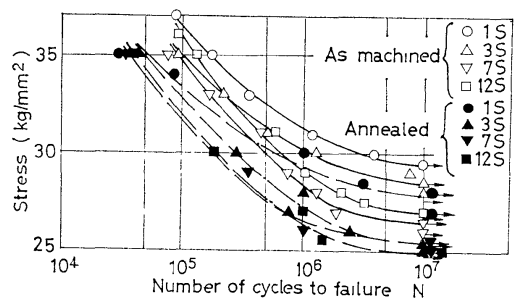

Fig. 6. $S-N$ curves at room temperature (rotating bending).

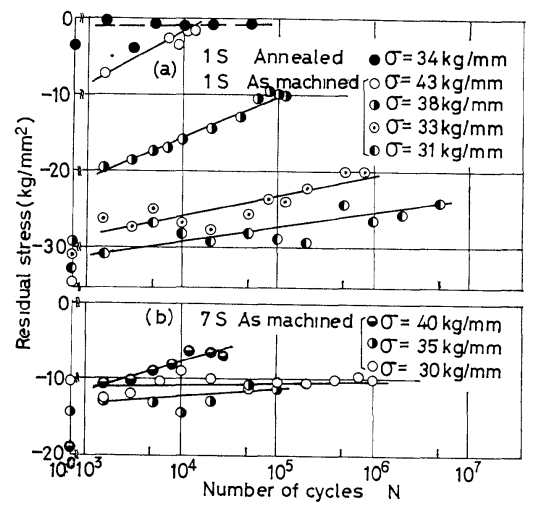

Fig. 7. Change of residual stress during fatigue test (rotating bending).

まし材の圧縮残留応力は, 応力繰返しとともに指数関 数的に減少する。 しかし, 疲労限度付近の応力で絽り 返した場合の圧縮残留応力はほとんど変わらないが, 1S と $7 \mathrm{~S}$ ではその絶対值偖があり，1S の方が疲労 限度の上昇に寄与しているはずである。一方，加工硬 化層はあらいもの活ど大きく, そ机比例して疲労限 度を上昇させるはずである。この両者はあらさによる 疲労限度の差を打ち消し合ら方向にある。また，焼な まし材では, 残留応力と加工硬化が注湆消滅している。 したがって，室温において両材であらさによる疲労限

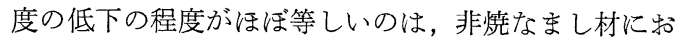
いて上述の二つの効果が相殺し，あらさの切欠き作用 だけが効果的であったと考觉られる。

$250^{\circ}$ C 亿拈汁る試験結果をFig. 8 亿示寸。非焼なま

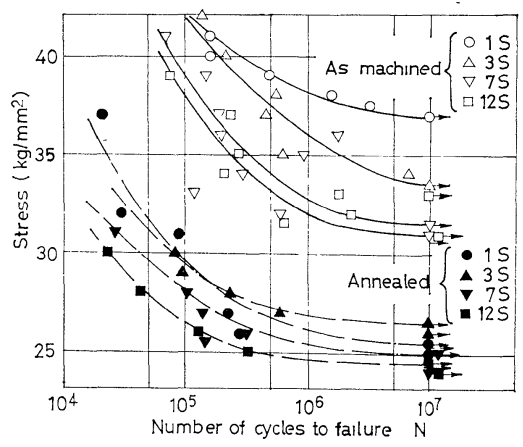

Fig. 8. $S-N$ curves at $250^{\circ} \mathrm{C}$ (rotating bending). 
し材と焼なまし材では，はっきり 2 群に分かれ，关れ ぞれあらいもの活ど疲労強度が低下する。非焼なまし 材の $1 \mathrm{~S}$ と $12 \mathrm{~S}$ の疲労限度の差は $6.0 \mathrm{~kg} / \mathrm{mm}^{2}$, 焼 なまし材のそれは $1.0 \mathrm{~kg} / \mathrm{mm}^{2}$ である。焼なまし材 の方があらさ，すなわら，切欠きによる疲労限度の低 下が少ないのは，焼なましにより切欠き感度が低下乙 ているためと考光られる。また，焼なましたより疲労 限度が $6.5 \sim 11.5 \mathrm{~kg} / \mathrm{mm}^{2}$ 低下するのは，加工の際饮 生じた転位が暁なましによって減少し，ひずみ時効に よる強化作用が減少したためと考兄られる。

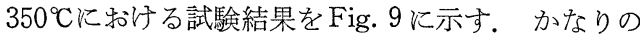
ばらつきがあるが，高応力に括いては非焼なまし材， 焼なをし材ともに，添淁あらいものほど疲労強度が低 下する，疲労限度付近では両材ともにわずかではある が，あらいものほど疲労強度が増加している，長時間 高温にさらされる疲労限度に近い応力で酸化スケー ルの発生により, 表面あらさの差の減少が観察され, そのために疲労限度の差がなくなったと考光られる。 また，両材とも $250^{\circ} \mathrm{C}$ の場合と同様に法っきり 2 群 に分かれ，焼なましによる疲労限度の低下は8.5 9.5 $\mathrm{kg} / \mathrm{mm}^{2}$ である。

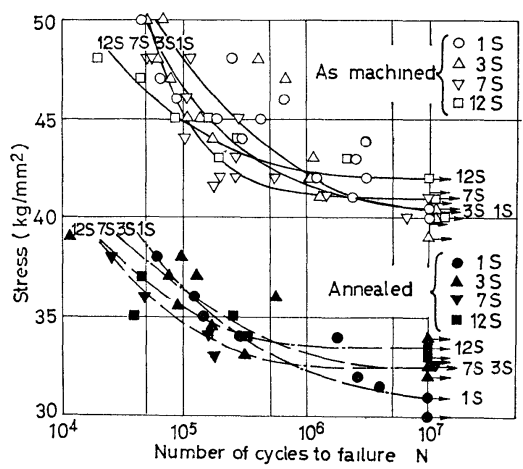

Fig. 9. $S-N$ curves at $350^{\circ} \mathrm{C}$ (rotating bending).

この材料の $350^{\circ} \mathrm{C}$ 亿打ける疲学強度のばらつきを調 べるために，1S の非焼なまし材を用いて，室温では 応力 $30 \mathrm{~kg} / \mathrm{mm}^{2}$ (応力過大率 $1.7 \%$ )， $350^{\circ} \mathrm{C}$ では応力 $44 \mathrm{~kg} / \mathrm{mm}^{2}$ (応力過大率 $8.6 \%$ ) で 5 本ずつの試験片 を用いて回転曲林疲労試験を行なった結果によると，

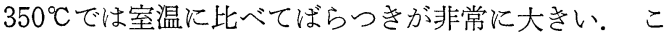
れは 1S が 0.5〜1.3S の範囲のあらさを代表するた めに，あらさのばらつきと，表面あらさの製作に伴う きわめて微妙な加工の程度の差が，ひずみ時効の最も

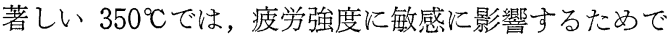
あると考光られる。

$250^{\circ} \mathrm{C}$ では $350^{\circ} \mathrm{C}$ ほどひずみ時効の影響が著しくなく， 疲労強度のばらつき拉よび繰返し応力による硬化の程 度が異なるため, $250^{\circ} \mathrm{C}$ と $350^{\circ} \mathrm{C}$ 亿和いてあらさと疲労
強度の関係の傾向が一致しないものと考光られる。

\section{$3 \cdot 2$ 引張圧縮疲労試験}

$3 \cdot 2 \cdot 1$ かたさ分布および残留応力 表面のかた さ和よび加工硬化層の深さは回転曲げの場合と注ぼ同 じである。しかし，3S，7S 拈よび $12 \mathrm{~S}$ の残留応力は 回転曲げの場合とやや異なる。.これはFig. 1 亿示すよ らに試験片の形状寸法の相違による剛性の差に原因す ると考光られる。

$3 \cdot 2 \cdot 2$ 室温, $250^{\circ} \mathrm{C}$ および $350^{\circ} \mathrm{C}$ における疲労 試験 $1 \mathrm{~S}$ の非焼なまし材に扝ける温度と疲労強度の 関係は，Fig. 5 の回転曲げの場合と全く一致した傾向 を示した．室温での試験結果を Fig. 10 に示す，疲労 限度は回転曲げのそれより $4 \sim 5 \mathrm{~kg} / \mathrm{mm}^{2}$ 低いが， らさと疲労強度の関係は回転曲げの場合とほぼ同じで, あらいものほど疲労強度が低下する。

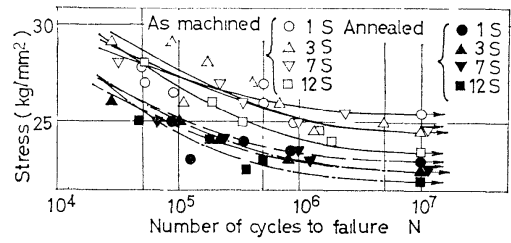

Fig. 10. $S-N$ curves at room temperature (push pull).

$250^{\circ} \mathrm{C}$ 亿和ける試験結果をFig. 11 亿示す。非焼なま し材と焼なまし材では，はっきり 2 群に分かれ，そ机 ぞれ $1 \mathrm{~S}$ の疲労強度が最も大きく，3S，7S 和よび $12 \mathrm{~S}$ ではあらさと疲労強度の相関がみられない，疲労限度 は回転曲げの場合より $8.5 \sim 12.5 \mathrm{~kg} / \mathrm{mm}^{2}$ 低い。 た，痜なましによって疲労限度は $7.5 \sim 8.0 \mathrm{~kg} / \mathrm{mm}^{2}$ 低下する。

$350^{\circ} \mathrm{C}$ に和ける試験結果をFig. 12 に示す。非焼なま し材ではあらいものほど著しく疲労強度が低下するが， 焼なまし材ではあらさと疲労強度の相関があまりみら れない。このように非焼なまし材では回転曲げの場合 と非常に異なった傾向を示すのは, $350^{\circ} \mathrm{C}$ の引張圧縮 では回転曲げより繰返 し応力が $6.5 \sim 17.5 \mathrm{~kg} / \mathrm{mm}^{2}$

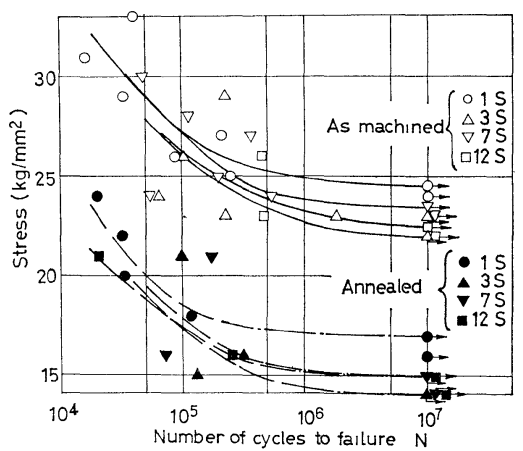

Fig. 11. $S-N$ curves at $250^{\circ} \mathrm{C}$ (push pull). 


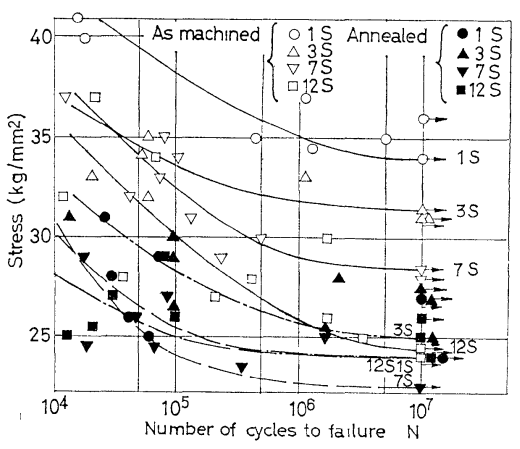

Fig. 12. $S-N$ curves at $350^{\circ} \mathrm{C}$ (push pull).

低いため，表面あらさが酸化スケールとして脱落する

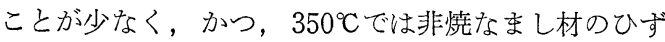
又時効の影響が著しいため゙に，表面あらさによる切欠 き作用が増加することが原因と考学られる。

\section{$3 \cdot 3$ 表面あらさの影響}

Fig. $13(\mathrm{a})$ は回転曲げ疲労試験結果より，1S の試験 片の疲労限度を基準とした各あらさの試験片の疲労限 度の低下率を示す。ここで， $\sigma_{1 \mathrm{~S}}$ は $1 \mathrm{~S}$ の試験片の疲 労限度， $\sigma_{2 s}$ は他のあらさの試験片の疲労限度を示す. 室温の場合，あらさによる疲労限度の低下率は非焼な まし材と焼なまし材では，汪ぼ同じであるが，250 拈よび $350^{\circ} \mathrm{C}$ の場合はかなりの差を生じる．Fig. 13 (b)の引張圧縮の場合も全く同様な傾向を示す。

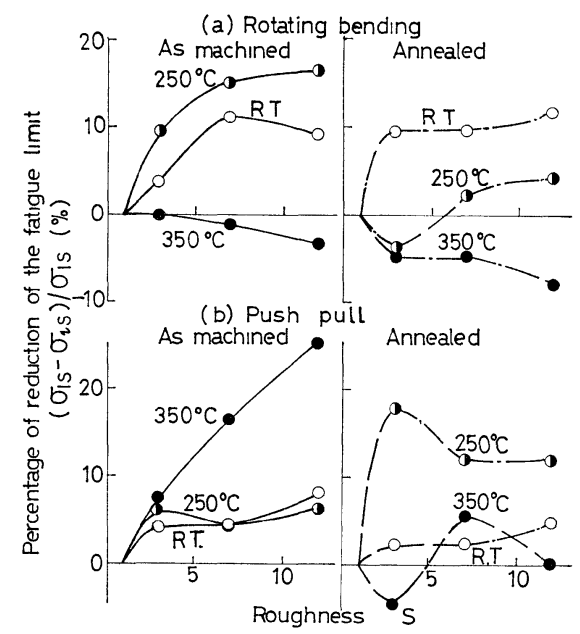

Fig. 13. Reduction of the fatigue limit caused by surface roughness.

このように室温では両材であらさによる疲労限度の 低下率がほぼ同じになるのは，あらさによる切欠き作 用が疲労限度に最も大きく影響するためである。他方，

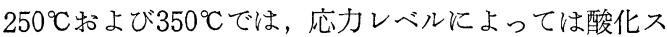
ケールが発生してあらさの影響が減少する反面, ひず み時効による強化の影響が著しく，かつ，ばらつきを 有するため，上述のような複雑な結果が生じたと考光
られる。

\section{$3 \cdot 4$ 焼なましの影響}

Fig. 14 (a)は，回転曲げ疲労試験に扣汀る焼なまし による疲労限度の低下率を示す。ここで， $\sigma_{M}$ および

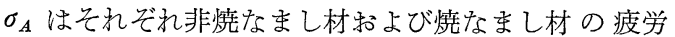
限度を示す。室温では $5 \sim 10 \%, 250^{\circ} \mathrm{C}$ 和よび $350^{\circ} \mathrm{C} て ゙ 、$ は約 $20 \%$ である. Fig. 14 (b)は引張圧縮の場合であり， 室温では回転曲げの場合とほぼ同じであるが，高温で はかなり異なった傾向を示し，250 Cでは 30〜 35\%， $350^{\circ} \mathrm{C}$ では $2 \sim 30 \%$ 低下する。 このように $250^{\circ} \mathrm{C}$ おび $350^{\circ} \mathrm{C}$ で回転曲げと引張圧縮の低下率が異なるのは, 回転曲げに比べて引張圧縮の場合は応力レベルが低い ために酸化スッールの発生が少なく, あらさによる切 欠き作用の影響が大きいためと考劣られる。

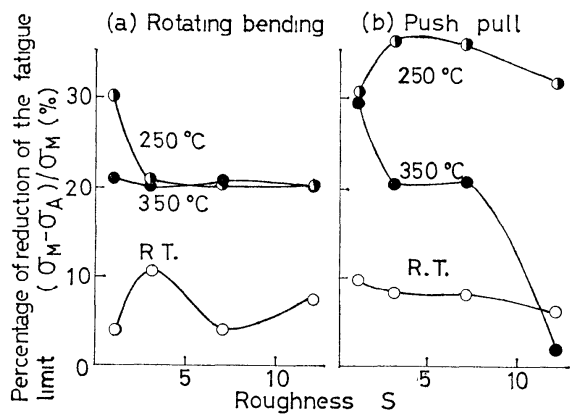

Fig. 14. Reduction of the fatigue limit caused by annealing.

\section{4 結 言}

$0.29 \% \mathrm{C}$ 炭素鋼を用いて，4 種類のあらさの試験片

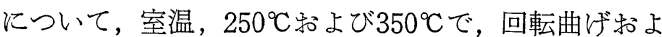
び引張圧縮疲労試験を行ない，あらさとその製作に伴 ら加工変質層の疲労強度に及ぼす影響を調べた結果, 次の結論を得た。

（1）室温では，あらいものほど疲労強度が低下し， あらさによる切欠き作用の影響が大きい.

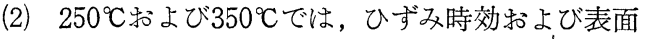
あらさによる疲労強度のばらつき, 回転曲げと引張圧 縮の応力レベルの差, 酸化スケールによるあらさの変 化, 繰返し応力によるかたさの変化などにより, あら さと疲労強度の関係に一定した傾向がみられない。

（3）非焼なむし材と焼なむし材の $S-N$ 曲線は $250^{\circ} \mathrm{C}$ と $350^{\circ} \mathrm{C}$ では，はっきりと 2 群に分かれる。

終わりに，本研究についてご討論いただいた東京都 立工科短期大学 川田雄一学長ならびに東京都立大学 宮川松男教授，児玉昭太郎助教授に感謝の意を表しま 于.

（昭和48年11月21日 シンポジウム「疲労における最近の諸問題」にて 講演) 


$$
\text { 参 考 文 献 }
$$

1）横山信三, 中野典彦, 木村陽次, 岐阜大学工学部研究報 告, No. 18, 54 (1968).

2）たとえば, 河本 実, 西岡邦夫, 乾 幸人, 土谷富士雄, 材料試験, 4, 42 (1955); 渡辺十郎, 荒木田豊, 日本機 械学会論文集, 29, 696 (1963); 竹内勝治, 材料, 16,
144 (1967).

3）安藤善司, 土田幸滋, 中野典彦, 材料学会, シンポジウ ム 疲労に和ける最近の諸問題, p. 48 (1973).

4) 安藤善司, 加藤容三, 清水達三, 三芳功達, 日本機械学 会論文集, 26, 86 (1960). 